\title{
HISTORIČNA GEOGRAFIJA HRVATSKE
}

\author{
Nikola Glamuzina, Borna Fuerst-Bjeliš: \\ Historijska geografija Hrvatske. Sveuči- \\ lište v Splitu, Filozofski fakultet, 312 str. \\ Split, 2015
}

Historijska geografija Hrvatske je delo avtorjev Glamuzine in Fürst-Bjeliševe, ki sta ga pripravila kot učbenik za študij istoimenskega predmeta na splitski filozofski fakulteti. Predmet izvajajo na področju zgodovine, zato je koncepcija učbenika kakor tudi razumevanje njegove medpredmetne povezljivosti že v osnovi meddisciplinarno, torej med geografijo in zgodovino. Vsebinsko gledano pa je učbenik z zgodovinsko metodo prikazana geografska stvarnost $\mathrm{v}$ kronološko-tematskem ter podredno še regionalnem zaporedju. 312 strani besedila je razdeljeno na 12 poglavij, pregled literature ter sezname grafičnih prilog. Obravnavana obdobja so zaradi zgodovinskih vezi merodajna v več pogledih tudi za slovensko državno ozemlje.

Interdisciplinarna raziskovalna disciplina posebej izpostavlja pomen časovne razsežnosti in njegovo vlogo v spremembah geografske stvarnosti. Čas je torej bistveni dejavnik, vendar ne sam po sebi, temveč zaradi kombinacije različnih družbenih in političnih vplivov, ki učinkujejo na vsakokratne družbene strukture, te pa oblikujejo kulturno pokrajino. V delu je le skromna pozornost odmerjena vplivu naravnih procesov; tako ostaja vtis, da je v metodološkem instrumentariju te discipline prisotna predvsem podmena antropogenih dejavnikov oblikovanja kulturne pokrajine ter seveda tudi družbe. Toliko bolj pa sta avtorja izpostavila gledanje in reakcije človeških družb v določenem časovnem obdobju in regionalnem kontekstu. Taka zgodovina je torej časovno opredeljena veda o okolju ter predvsem, kako človek (oziroma družba) percipira kategorijo okolja ne glede na to, v kolikšni meri je to lokalno ali regionalno rezultat naravnih ali pa na drugi strani človeških vplivov. Ker je pri interpretaciji človekovih ravnanj $\mathrm{v}$ preteklosti bistvenega pomena tudi poznavanje miselnosti preteklih družb, je disciplina tematsko široka in zelo zahtevna. Historična (zgodovinska) geografija ni zgodovina geografske vede, temveč geografska interpretacija zgodovinskih procesov. Pri tem predstavljajo državne tvorbe prvi (politični) okvir, na katerega se naslanja upravno-administrativna členitev in gospodarski sistem. Te strukture so na preučevanem primeru hrvaških teritorijev pustili najbolj markantne in obstojne sledi. $\mathrm{V}$ teh okvirih so se oblikovali sistemi poselitve in kultivacije zemljišč kot glavnih tvorcev pejsaža. Sledi razvoj različnih neagrarnih panog, upravno-administrativne razdelitve in socialne, kulturne in politične stratifikacije vsakokratnih družb. Interpretacija je 
tematsko-kronološko zasnovana in uporablja vzročno-posledično logiko in argumentacijo virov podatkov, informacij in materialnih artefaktov.

Prebiranje tega dela razkrije bralcu drugačen, genetsko-interpretativno obogaten pogled na sosednjo državo. Na prvi pogled je manj izrazito stična kot Slovenija, a po drugi strani (predvsem v luči zgodovinskih procesov) je izrazito sestavljena. Če postavimo ta vedenja $\mathrm{v}$ vlogo sodobnega regionalnega razvoja ter razumevanja njenega geopolitičnega položaja, je omogočeno razumevanje Hrvaške skozi prizmo mozaične stvarnosti, ki so jo gradili beneški, mleški in dubrovniški državni sistemi, spreminjali vplivi turške osmanske države in politično-teritorialno v večji meri definirali ogrski in habsburški vplivi, nadgradili obe jugoslovanski državi ter dajejo sodobni družbeni in prostorski pečat čas po osamosvojitvi leta 1991. S tem grobim orisom pa se brskanje po prepletanju omenjenih vplivov, bodisi časovno vzporedno bodisi zaporedno, ter ugotavljanje človekovega prostorskega ravnanja v izbranih časovnih sekvencah šele resno začne. Zgodovinska geografija se tako manifestira kot široka interpretativna med-veda, pomožna veda tako geografije kot zgodovine, v smislu vednosti o (predvsem državnem) prostoru pa pravzaprav nadgradnja.

Jernej Zupančič 